\title{
A LEAN MANAGEMENT APPROACH FOR THE ROMANIAN TEXTILE AND CLOTHING INDUSTRY
}

\author{
Adriana DIMA \\ Bucharest University of Economic Studies, Bucharest, Romania \\ adriana.dima@man.ase.ro \\ Ruxandra DINULESCU \\ Bucharest University of Economic Studies, Bucharest, Romania \\ ruxandra.dinulescu@man.ase.ro
}

\begin{abstract}
Lean management represents a systematic approach used for identifying and eliminating waste and non-value added activities from different industries, including the textile industry. Even if the lean manufacturing concept has shown important results in continuous process industry, the textile industry represents a good area for implementing this methodology targeting as a main objective the action of eliminating waste, thus reducing costs and therefore, increasing productivity. Being a customer oriented process, the system has the ability to eliminate a significant part of waste from the Romanian textile industry. As a result, this is an incipient study aimed to present the benefits of implementing Lean Management in the Romanian textile industry, through its improvement tools, as well as presenting a theoretical economic impact for a textile company. Also, taking into consideration that Lean Management is not yet applied in the Romanian textile field, the study will present a part of the areas which would need the Lean implementation, as well as further actions to be taken in order to improve productivity in textile industry.

Keywords: Textile and clothing industry, Lean Management, waste, productivity
\end{abstract}

\section{INTRODUCTION}

The textiles and clothing industry has a long tradition in Romania, with organizations that have more than 80 years of experience. The Romanian companies in this field operate on a very small profit margin, because of the fact that the industry relies heavily on an assembling type of production, where the commercial addition is low (Bratucu et al., 2017). Lohn represented an advantage for the light industry in Romania in the short and medium term, ensuring the transfer of technology, increasing the number of employees, competitiveness and managerial capacity. Jobs created through the implementation of the lohn system are not sustainable, running the risk of being transferred to other countries that offer lower labour costs (Girneata, 2015). Analysing the value chain in the lohn work 
system, it was found that the highest added values correspond to the links which are not part of the national chain. These include raw materials, accessories, marketing, distribution, and are provided by the external beneficiary. The smallest influences in the value chain belong to the internal links: assembly of the finished product, storage of raw materials and finished products, finishing, packaging. In the long term, measures to increase the competitiveness of the textile and clothing sector at international level should aim at reorienting production to exports directly from its own production (Gîrneaţă et al., 2015). In terms of production, this can be achieved by: producing high quality products; the development of own brands and the image of products and processes (Girneata \& Dobrin, 2015), complete product development, continuous training and improvement of the garment industry personnel, in order to increase labor productivity, refurbishment of the fabrication flows of the clothing products by purchasing the advanced equipment, computerized systems.

The disappearance of traditional export markets in the communist era, the decline of the Romanian industry after 1990, geographical proximity to the EU market and the investment effort of technological adaptation have led the industry to develop a production focused on assembling (Vasile \& Maria, 2018). Even after the decline of the Romanian industry after 1990, production focused on the assembly of products remained the main activity of the companies all the industrial fields, which allowed the survival of the industry, but not its development (Dobrin, Dima \& Tanase, 2017).

During the period 2008 - 2013, the economic crisis has strongly influenced the textile companies in Romania that went through a period of decline, losing contracts in favor of the Asian market. Despite the fact that at the European level innovation enabled the textile industry to maintain the competitiveness through investments in niche textiles, for Romania the absence of sufficient foreign investments and restrictive loaning conditions restricted these chances.

What is lacking in the industry is the innovative input, on the one hand, and the direct connections to the outlets that would provide them with a higher added value, on the other hand (Tudor, 2018). Thus, given that more than $70 \%$ of the garment companies' activities are assembled, the industry is based on a competitiveness that is on the one hand, on the one hand, on the low cost of the labor force, and on the other hand on the investments in technology.

The textile industry survived due to the reorientation towards the assembly production (Cuc et al., 2015), because in competition with the large globalized companies, Romanian brands they had minimal chances to survive by themselves (Gîrneaţă, 2013). The competition focuses on the quality of the assembly and its competitive price, and Romania's competitors are Asian countries, Turkey or countries in the Bacon-Mediterranean area. In most of these countries the workforce is very cheap. The monthly 
wage does not exceed 100 dollars at most and there is no minimum wage imposed by governments, and the legislation on employee protection is virtually non-existent.

Most of the companies that use the Romanian labor force for assembly production are from Great Britain, Spain, Germany, Italy or France. These countries own the mass production market, as well as haute-couture productions, and are the main partner countries in assembling production executed in Romania. In this case, a much higher profit margin is involved.

\section{ERRORS VISIBLE IN THE ROMANIAN TEXTILE AND CLOTHING INDUSTRY}

Before proceeding with our research, we asked a couple of shop supervisors which are the main causes that produce the errors from the textile industry. The result is shown in the diagram below, along with a couple of root causes (only the major types of defects were taken into consideration):

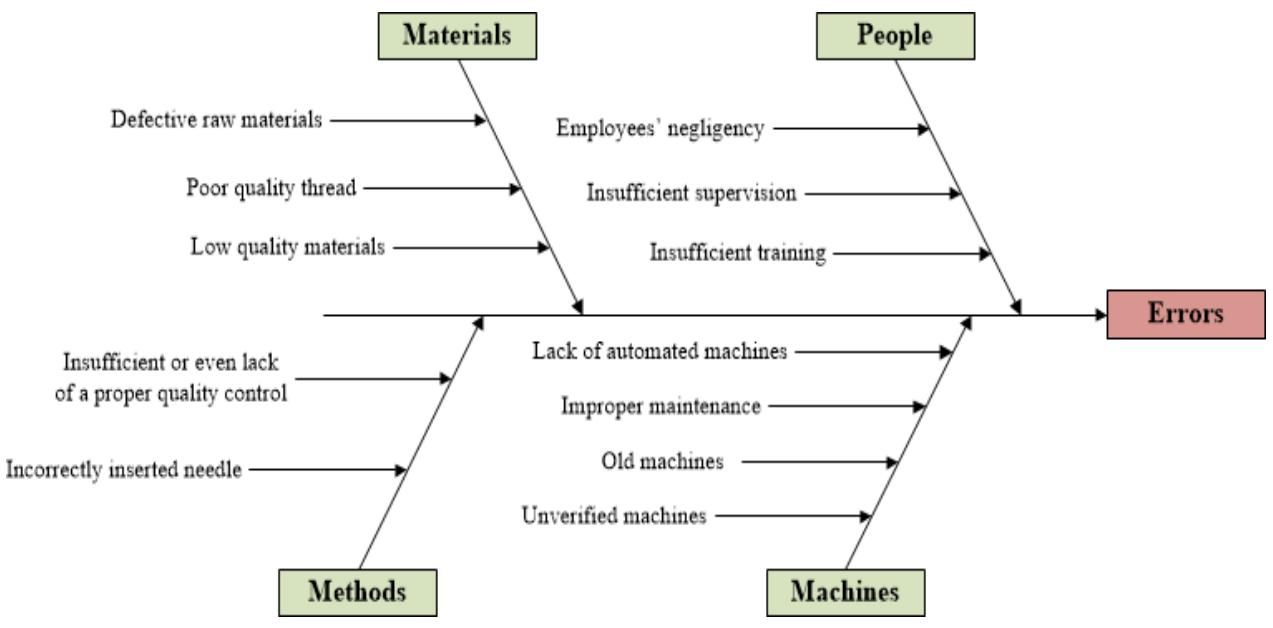

FIGURE 1. CAUSE AND EFFECT DIAGRAM APPLIED TO THE TEXTILE INDUSTRY

Source: The authors

\subsection{Statistical Analysis of the Romanian Textile and Clothing Industry}

Furthermore, for a detailed analysis of the garments and textiles sector at national level, data from statistical yearbooks were selected from 2004 and up to 2016, the last year for which there are information published by the National Institute of Statistics. The range includes the period before the full liberalization of world trade in textiles, garments clothing by removing any quantitative restrictions in 2005 , the economic crisis that was felt globally in 2008 , and in Romania in 2012, as well as the years of revival. The indicators that have been analysed are: production, intermediate consumption and gross 
Dima A., Dinulescu R.

A LEAN MANAGEMENT APPROACH FOR THE ROMANIAN TEXTILE AND CLOTHING INDUSTRY

value added for the manufacture of textiles and clothing, number of enterprises and exports of goods in this sector of activity.

TABLE 1. PRODUCTION, INTERMEDIATE CONSUMPTION AND GROSS VALUE ADDED FOR MANUFACTURE OF TEXTILES, WEARING APPAREL AND LEATHER PRODUCTS (MILLION LEI CURRENT PRICES)

\begin{tabular}{|l|c|c|c|}
\hline Year & Production & Intermediate consumption & Gross value added \\
\hline 2004 & 12518,7 & 7489,0 & 5029,7 \\
\hline 2005 & 12711,3 & 7486,8 & 5224,5 \\
\hline 2006 & 13715,8 & 8112,6 & 5603,2 \\
\hline 2007 & 15610,3 & 9101,1 & 6509,2 \\
\hline 2008 & 16628,0 & 9703,1 & 6924,9 \\
\hline 2009 & 18878,6 & 11152,0 & 7726,6 \\
\hline 2010 & 19523,8 & 8380,0 & 11143,8 \\
\hline 2011 & 23004,0 & 9626,8 & 13377,2 \\
\hline 2012 & 17351,6 & 8935,1 & 8416,5 \\
\hline 2013 & 28642,3 & 14797,7 & 13844,6 \\
\hline 2014 & 14685,2 & 14685,2 & 13163,3 \\
\hline 2015 & 27768,8 & 14346,2 & 13422,6 \\
\hline
\end{tabular}

Source: Romanian Statistical Yearbooks (2005 - 2017), National Institute of Statistics,

http://www.insse.ro/cms/ro/content/anuarele-statistice-ale-romaniei

Table 1 illustrates that the production expressed in million lei current prices had a constant evolution in the analyzed period, except for the year 2012, when it registered a decrease due in large part to the economic crisis experienced later in the country than at the European and world level. Intermediate consumption and gross value added led to the same growth trend, but declined in 2010 and also in 2012. It is noted that all three indicators doubled their value from 2004 to 2015 , the last year for which data were published in INS yearbooks.

Table 2 shows the dramatic reduction in both the number of companies and the number of employees in 2016 compared to 2005. This reduction began in 2009, giving timid signs of recovery in 2014, but this growth was not sustained until the end of the period under review. This decrease can be explained by the fact that when Romania joined the European Union the salaries in the country were increased, and the workforce in the garments and textiles sector, paid with the minimum wage, became less attractive to the foreign companies that collaborated in lohn system. Also, because of the shortage of contracts, 
Dima A., Dinulescu R.

A LEAN MANAGEMENT APPROACH FOR THE ROMANIAN TEXTILE AND CLOTHING INDUSTRY

many of the companies that only provided the workforce to the foreign partners had to leave the market due to the lack of contracts.

TABLE 2. NUMBER OF ENTERPRISES AND EMPLOYEES IN THE TEXTILE AND CLOTHING SECTOR

\begin{tabular}{|l|c|c|c|c|}
\hline \multirow{2}{*}{ Year } & \multicolumn{2}{|l|}{ Manufacture of textiles } & \multicolumn{2}{l|}{ Manufacture of wearing apparel } \\
\cline { 2 - 5 } & $\begin{array}{c}\text { Number of } \\
\text { enterprises }\end{array}$ & $\begin{array}{c}\text { Average number of } \\
\text { employees }\end{array}$ & $\begin{array}{c}\text { Number of } \\
\text { enterprises }\end{array}$ & $\begin{array}{c}\text { Average number of } \\
\text { employees }\end{array}$ \\
\hline 2005 & 2493 & 78344 & 5849 & 286214 \\
\hline 2006 & 2440 & 70494 & 5743 & 255889 \\
\hline 2007 & 2365 & 62987 & 5698 & 224194 \\
\hline 2008 & 2343 & 55418 & 5410 & 188212 \\
\hline 2009 & 1631 & 28257 & 5313 & 167931 \\
\hline 2010 & 1499 & 27763 & 4480 & 154547 \\
\hline 2011 & 1317 & 28862 & 4111 & 159784 \\
\hline 2012 & 1295 & 28756 & 4231 & 159891 \\
\hline 2013 & 1279 & 29608 & 4378 & 158034 \\
\hline 2014 & 1312 & 30624 & 4585 & 158577 \\
\hline 2015 & 1325 & 31861 & 4759 & 156256 \\
\hline 2016 & 1316 & 31056 & 4812 & 148651 \\
\hline
\end{tabular}

Source: Romanian Statistical Yearbooks (2005 - 2017), National Institute of Statistics,

http://www.insse.ro/cms/ro/content/anuarele-statistice-ale-romaniei

TABLE 3. EXPORT OF GOODS (MILLION EURO)

\begin{tabular}{|l|c|c|c|}
\hline Year & Total Romanian exports & Textile products & Wearing apparel \\
\hline 2005 & 22255 & 909 & 3334 \\
\hline 2006 & 25850 & 1017 & 3179 \\
\hline 2007 & 29549 & 1053 & 2880 \\
\hline 2008 & 33725 & 667 & 2836 \\
\hline 2009 & 29084 & 633 & 2244 \\
\hline 2010 & 37360 & 754 & 2382 \\
\hline 2011 & 45292 & 893 & 2679 \\
\hline 2012 & 45069 & 893 & 2678 \\
\hline 2013 & 49562 & 954 & 2711 \\
\hline
\end{tabular}


Dima A., Dinulescu R.

A LEAN MANAGEMENT APPROACH FOR THE ROMANIAN TEXTILE AND CLOTHING INDUSTRY

\begin{tabular}{|l|l|l|l|}
\hline 2014 & 52466 & 1017 & 2816 \\
\hline 2015 & 54610 & 1091 & 2808 \\
\hline 2016 & 57392 & 1192 & 2836 \\
\hline
\end{tabular}

Source: Romanian Statistical Yearbooks (2005 - 2017), National Institute of Statistics,

http://www.insse.ro/cms/ro/content/anuarele-statistice-ale-romaniei

Table 3 shows the Total Romanian exports expressed in million euro and the value for the two branches of activity of the analyzed domain. Total Romanian exports doubled their value in 2016 compared to 2005, but the textile and clothing sector has a very small share in this total. Both branches of activity: textiles and wearing apparel have inconsistent evolutions from year to year, highlighting the unpredictability of this industry.

\section{LEAN MANAGEMENT IN THE ROMANIAN GARMENT INDUSTRY}

When we think about a qualitative textile industry we can imagine a system with zero defects or errors that might result in customers' dissatisfaction or claims. Therefore, a qualitative textile industry should be oriented on lower costs and higher processes' level (Juran, 1998), as well as performance, reliability, durability, visual and perceived quality of the garment.

A method that could improve the process by eliminating waste and increase efficiency in the textile industry, is Lean Management. Though is not applied in the Romanian textile industry, the method represents a high potential for this field.

Therefore, our paper is an ongoing study that focuses on presenting a theoretical part of how Lean Management could improve and eliminate waste from the Romanian textile industry.

Lean management represents an approach that targets an improved process quality and elimination of everything that could create waste and not adding value for the customer (Furterer, 2014).

\subsection{Types of wastes for the clothing and textile industry}

In the textile industry, the value-added activities refer to those activities that could transform or change the form of a certain material. The rests of the activities, meaning those that add cost but not value to the product are called non-value added activities. In garment manufacturing, there are some activities that don't add value but necessary. For example, transportation of cuttings (bundles) to the sewing department is an example of a non-value added but, at the same time, an essential task. 
The seven types of wastes often described in Lean methodology and developed by Toyota focus on non-value-added activities, wastes, including all the activities that consume financial resources, time, and people, but without creating any value for the customer (Arthur, 2011).

In the following paragraphs we will describe these seven types of wastes and after that, we will see how those apply to our textile industry.

The first seven types of wastes (or Muda - the Japanese term) were identified by Taiichi Ohno (19121990), the Toyota executive (Womack, 2003).

The first step would be to identify these wastes and associate them with our textile industry. After that, we should take into consideration the textile industry processes where these wastes are present and in the end, present how Lean management could be used in order to reduce these wastes and increase process efficiency.

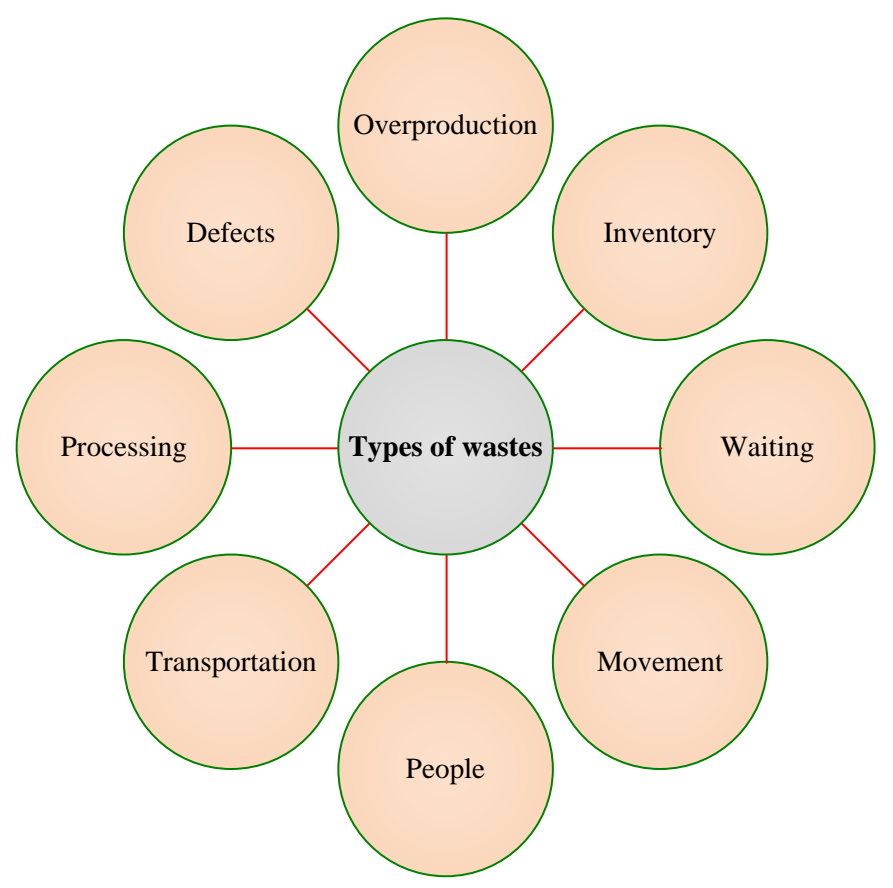

FIGURE 2. TYPES OF WASTES VISIBLE IN THE TEXTILE INDUSTRY

Source: The authors

However, we will start by describing them below and exemplifying how they appear in the Romanian textile industry:

- $\quad$ Overproduction - this type of waste appears pretty often in every textile fabric, not only in the Romanians one. Overproduction means that the textile industry produces sooner, faster or in bigger quantities than the client demands. 
In the textile industry, more precisely, in the garment factories, overproduction could be found in the cutting department and in sewing operations. For example, if there is a daily production demand from sewing of 2000 pieces, and the factory cuts more than the required quantity (demanded quantity), the factory is producing excess units of garments.

- Inventory - inventory appears, as we have already mentioned, because of overproduction.

When the textile fabrics produce or process more than it is needed (overproduction), inventory appears (raw materials, work in progress and even finished goods that have no value added). The main disadvantage of this inventory is that it requires space for deposit and sometimes, additional costs.

A lot of inventory is usually found in fabric or trim stores, cutting racks, finishing trolleys.

- Waiting - this waste is visible for people or parts that wait for a work cycle to be completed.

In garment factories, waiting is found in all processes. Examples of waiting might be:

- When the sewing operators wait for cuttings (no feeding)

- When supervisors wait for final instruction and go ahead for quality approvals

- Merchandisers wait for buyer approvals.

Waiting is a visible waste in manufacturing since operators and other employees produce nothing while they wait for work. Also, other examples of such waste might be - delays in sourcing materials, cutting delays due to fabric approvals and consumption approval, etc.

- Movement (motion) - refers to the unnecessary movements of people, parts or machines within a process.

In workstations where operators sew garments, press-men press garments, workers finish and pack garments, excess motions exit. Sometimes excess motion at workstations is found due to poor training of workers in working methods and the habit of working in traditional ways.

- $\quad$ Transportation - refers to the unnecessary movements of people or parts between processes.

For example, moving cuttings from the cutting department to sewing lines, or transporting stitched garments from the sewing floor to the finishing department - these are actions that could be automated (thus reducing transportation) if used transportation rail in sewing line.

- Over-processing - the action of processing beyond the standard required by the customer.

In the garment industry, there are operations which might not be essential for the final look and construction. For example, multiple checking in finishing (initial checking, pre-final checking, and final checking).

- Defects - an action made not right from the first time which might include also the repetition or correction of the process. 
Examples of defects (or errors) in textile manufacturing could be the shade variation, wrong cutting, stitching defective garment etc. If defective garments are made, then the factory needs to alter and repair those defective garments before handing over to the customer. As always, the repair work costs money and time.

- $\quad$ People - some Lean specialists consider also that waste of human potential becomes more and more observable. In Romania, this kind of waste is often seen when employees' ideas about how their work might become more efficient are not taken into consideration or even ignored.

\section{CONCLUSIONS}

Romanian garment companies can survive only if they manage to invest in the latest generation of technologies. Otherwise, the loss of small and fragile competitive advantages discourages investment and can quickly lead to the loss of business relationships with the main operators in the outlets. Most employers show that the industry could absorb new employees, many jobs being in the industry, but it is very difficult to find people prepared or willing to attend a specialization course, which then engages in a textile factory.

It remains to be seen in the Romanian garment industry, but the signs are not encouraging. The accelerated growth of the minimum wage in the economy since 2017 struck the textile industry, mainly characterized by factories producing in lohn and for which raising the minimum wage on the economy has led to increased production costs, mass layoffs or closures of factories. International brands that locally produce lohn give up Romania and move production to countries where they find cheaper labor and have lower costs. In this scenario, the Romanian factories remain only with the option to work in the semilohn and to orient themselves to integrated services of creation and own design, which bring value to the production process.

Lean methodology is about people, and most of all is about the customers. When a client comes to a textile store and leaves with some sort of aversion about the staff or about the garments' quality, this means that something is missing, the quality is not good enough or something is not done the way it supposed to so that the client could leave satisfied.

This is why we consider that the Romanian textile industry needs to reinvent, and for that, it needs a method easy to understand by the employees that could lower the rate of producing waste of all sorts. Applying the Lean tools will not change an entire system overnight. Applying the Lean methodology and expecting instant results, means that the whole concept is misunderstood by the employees. They need, first of all, to understand the Lean concept, in order to work with it. Managers from the textile 
industries need to involve all the employees in presenting ideas about how the process could change in order to increase, for example, the garments' quality.

Lean management is about seeing the "the big picture" and then analyzing, process by process, what could be done in order to improve a certain action.

This is why a "lean garment system" should be a system that rearranges the processes in order to avoid the non-added value for the customers, and this is what Romanian textile industry needs.

Applying Lean Management in textile industry could generate a major impact from the industrial, financial as well as commercial point of view. Its main focus is based on producing according to the demand, quality, reduction of delivery times and also leading to customer satisfaction, by avoiding activities that do not add value. In this way, the production costs will decrease and the profits will increase (Gurumurthy \& Kodali, 2011).

\section{REFERENCES}

Arthur J. Lean Six Sigma for Hospitals. New York: McGraw Hill Education; 2011. 38-39

Bratucu, G., Epuran, G., Gârdan, D. A., Bumbas, F., Zamfirache, A., \& Gârdan, I. P. (2017). The evolution of textile and clothing industry in Romania: an analysis from the perspective of imports and exports determinants. Industria Textila, 68(2), 147.

Cuc, S., Gîrneață, A., lordănescu, M., \& Irinel, M. (2015). Environmental and socioeconomic sustainability through textile recycling. Industria Textila, 156.

Dobrin, C., Dima, A., \& Tanase, C. (2017). Statistical Analysis of Textile Industry at the European Union Level in Post Crisis Period. In Proceedings of the International Management Conference (Vol. 11, No. 1, pp. 474-480). Faculty of Management, Academy of Economic Studies, Bucharest, Romania.

Furterer S. Lean Six Sigma Case Studies in the Healthcare Enterprise. New York: Springer; 2014. 102

Gîrneaţă, A. (2013). The importance of clusters in the development of the textile and clothing industry. Network Intelligence Studies, 1(2), 83-89.

Girneata, A. (2015). The Evolution of the Textile and Clothing Industry-Romania: From Lohn to Loss. Revista Economica, 67(4), 176-187.

Girneata, A., \& Dobrin, C. (2015). Globalization and the Competitiveness of the European Textile and Clothing Industry. The Annals of the University of Oradea, 1102.

Gîrneaţă, A., Giurgiu, A., Dobrin, O. C., Popa, I., Popescu, D. I., Cuc, S., \& Voicu, L. (2015). Performance management practices in Romanian textile and clothing companies. Industria Textila, 66(2), 108-113.

Gurumurthy A., Kodali R. (2011): Design of lean manufacturing systems using value stream mapping with simulation. A case study. Journal of Manufacturing Technology Management. Vol. 22 No. 4 , 2011, pp. 444-473. Emerald Group Publishing Limited 1741-038X. DOI 10.1108/17410381111112640 Juran J., Blanton A. (1998), Juran's Quality Handbook. New York: McGraw Hill Education; 41-46

Romanian Statistical Yearbooks (2005 - 2017), National Institute of Statistics, http://www.insse.ro/cms/ro/content/anuarele-statistice-ale-romaniei 
Tudor, L. (2018). Change in Textile and Clothing Industry. Industria Textila, 69(1), 37-43.

Vasile, B., \& Maria, A. T. (2018). The analysis of the economic growth capacity in the Romanian clothing industry. Annals of 'Constantin Brancusi' University of Targu-Jiu. Economy Series, (2).

Womack J., Jones T. (2003) Lean thinking-Banish waste and create wealth in your corporation. New York: Free Press;. 15-20 